\title{
What "Persuades" God to Respond to the Psalmist's Cry? Use of Rhetorical Devices Related to "Vows of Future Praise" in Some Psalms of Lament
}

\author{
JUNE F. Dickie (UNIVERSITY OF KWAZULU-NATAL)
}

\begin{abstract}
Psalms of lament characteristically include affirmations of trust and sometimes a vow to praise God in the future. This article questions the motivation behind such vows by looking carefully at whether future praise is conditional on God's positive response and what other rhetorical devices are linked to the promise God makes. Attention is given to the nature of praise and lament psalms (considering the power dynamic) and foundational principles of Persuasion Theory. Five biblical psalms of lament are considered, with particular attention to their use of a vow and other persuasive tactics to encourage God to intervene. Although a vow of future praise (and other persuasive tactics) may be used, the psalmist's most critical means of persuasion (as apparent in Ps 88) is the character of the psalmist's covenant-partner.
\end{abstract}

KEYWORDS: Psalms of lament, Vows, Persuasion, Rhetorical devices

\section{A INTRODUCTION AND OVERVIEW}

Praise and lament are two responses to the covenant relationship between God and God's people. The differences between these two modes are discussed below, with particular focus on the power differential and the reciprocal promises which underlie the covenant relationship.

The focus of this article is on the vow in biblical laments. It is noted that this often follows a sudden change of mood in the psalmist and various reasons are proposed for what causes this, including two psychologically based theories, viz. those of "emotion-regulation" and a "hidden transcript." The first supports the idea of the psalmist working with God (building a stronger, empathic relationship, and developing an "inner voice," which may represent the divine

* Submitted: 15/04/2021; peer-reviewed: 26/07/2021; accepted: 16/11/2021. June F. Dickie, "What "Persuades" God to Respond to the Psalmist's Cry? Use of Rhetorical Devices Related to "Vows of Future Praise" in Some Psalms of Lament," Old Testament Essays 34 no. 3 (2021): 741 - 767. DOI: https://doi.org/10.17159/23123621/2021/v34n3a6. 
voice) and the latter having a disruptive agenda, aiming to undermine "official theology" (or "the public transcript"). ${ }^{1}$

The disruptive agenda includes various persuasive tactics which the psalmist employs. These become apparent when the language in some lament psalms is carefully studied with particular attention to the use of a vow of future praise. The discussion concludes by drawing together the main findings from the theory and its application to the five psalm examples.

\section{B NATURE OF PRAISE AND LAMENT}

Lament is the language of suffering whereas praise is the language of joy. Both suffering and joy are part of the normal human condition, and both lament and praise are essential in Israel's worship, implicit within the covenant.

A major difference between them is that praise legitimises the status quo with no expectation of change. Consequently, praise can lead to "the loss of "vital speech" (White 2006). ${ }^{2}$ In contrast, lament challenges the unquestioned authority and power of God, with no limits on the lamenter's speech before God. ${ }^{3}$ Communication in lament is two-directional, with God and the psalmist interacting together towards a changed situation. Indeed, for the Jewish people, "an adequate relationship with God requires a human voice that will speak out against every wrong perpetrated," even by heaven (my emphasis). ${ }^{4}$

\section{$1 \quad$ Lament as a challenge to God's power}

Williamson ${ }^{5}$ observes that "In Israel's laments before YHWH, issues of power are always at play," helping to "maintain the balance of power between YHWH and Israel." The "unmitigated supremacy" of God is questioned as the individual/community seeks a new relationship with YHWH. Once lament has broken the "conforming silence," there is no return to innocent praise, no going

1 "Official theology" is that which meets with general approval such as praise (James C. Scott, Domination, and the Arts of Resistance: Hidden Transcripts (Yale University Press, 1990). In contrast, lament (the "hidden transcript") subverts the established position.

2 James B. White, Living Speech: Resisting the Empire of Force (Princeton: University Press, 2006).

3 Walter Brueggemann, Old Testament Theology: Essays on Structure, Theme and Text (Minneapolis: Fortress Press, 1992), 29.

4 Walter Brueggemann, Theology of the Old Testament: Testimony, Dispute, Advocacy (Minneapolis: Fortress Press, 1997), 22.

5 Robert Williamson Jnr, "Lament and the Arts of Resistance: Public and hidden Transcripts in Lamentations 5," in Lamentations in Ancient and Contemporary Cultural Contexts (ed. Nancy C. Lee and Carleen Mandolfo; Atlanta: SBL, 2008), 67, 71. 
back to uncontested power. ${ }^{6}$ Everything must be reviewed. In particular, the sharing of power between the two parties must be redistributed.

This adjustment to the power relationship is necessary to prevent truth being compromised and so that justice can be restored. ${ }^{7}$ The voices of those who traditionally have been excluded from the conversation must be given preference to enable the centre to shift. ${ }^{8}$ By refusing to suppress or deny the raw edges of suffering and chaos, ${ }^{9}$ the official theology is disrupted and truth is elevated. For example, Job, by voicing his pain, "broke open settled truth... creating new possibility for an encounter with God." 10 In particular, Job's lament highlights the weakness in interpreting God's justice in a binary way ${ }^{11}$ and thus brings about a deeper understanding of the character of God.

The nature of biblical lament thus opens the door for a perspective which disrupts the traditional view of the motivation behind the psalmist's vow of future praise. Official theology would claim that God is always faithful to the covenant and always worthy to be praised, thus, the psalmist should not (or would not) try to manipulate God's actions towards him. However, by raising a complaint and accusing God, the psalmist decentres official theology, allowing the truth to be seen somewhere between the two extremes: that "God is always faithful" (implying blame lies with the sufferer) and "God is not reliable" (implying suffering is not deserved). ${ }^{12}$

Indeed, biblical lament serves a critical role in Christian theology by "articulating theological paradoxes, rather than a monolithic point of view."13 This grants a more responsible role to the psalmist, concerning which Brueggemann ${ }^{14}$ claims: "Where there is lament, the believer is able to take

6 Walter Brueggemann, "Lament as Wake-up Call (Class Analysis and Historical Possibility)," in Lamentations in Ancient and Contemporary Cultural Contexts (ed. Nancy C. Lee and Carleen Mandolfo; Atlanta: SBL, 2008), 228.

7 Michel Foucault, Discipline and Punish: The Birth of the Prison (Translated by Alan Sheridan; New York: Vintage, 1979).

8 Carol L. Hess, "Becoming Mid-wives to Justice: A Feminist Approach to Practical Theology," in Liberating Faith Practices: Feminist Practical Theologies in Context (ed. Denise Ackermann and Riet Bons-Storm; Leuven: Peeters, 1998), 65-67.

9 Johan Cilliers, "Breaking the Syndrome of Silence: Finding Speech for Preaching in a Context of HIV and AIDS," Scriptura 96 (2007): 394.

10 Brueggemann, "Lament as Wake-up Call," 223.

11 Carleen Mandolfo, "Talking Back: The Perseverance of Justice in Lamentations," in Lamentations in Ancient and Contemporary Cultural Contexts (ed. Nancy C. Lee and Carleen Mandolfo; Atlanta: SBL, 2008), 50.

12 Carleen Mandolfo, God in the Dock. Dialogic Tension in the Psalms of Lament (Sheffield: Sheffield Academic Press, 2002), 194.

13 Mandolfo, God in the Dock, 161.

14 Walter Brueggemann, The Psalms and the Life of Faith (Minneapolis: Fortress Press, 1995), 103. 
initiative with God and so develop the ego-strength that is necessary for responsible faith. The absence of lament makes a religion of coercive obedience the only possibility." Jesus exemplifies such an attitude of "resistant submission" towards God when he not only pleads, "Father, remove this cup from me" (resistance), but also affirms "not my will but yours be done" (submission). It is possible, then, to have an attitude of "resistant submission" towards God, and this could underlie the psalmist's vow in lament psalms.

The basis for the relationship between God and God's people is the covenant. Essentially, the covenant involves reciprocal promises and it is on the basis of God's promise that the lamenter brings his "case" before God. As part of trying to get God to act (and implement God's part of the reciprocal arrangement), the lamenter may make a promise (or vow) to God. Thus, the next section explores the covenant promises as part of the background to the psalmist's rhetoric in lament psalms.

\section{Relationship underlying lament: The covenant between God and God's people}

The notion of a covenant between God and God's people is first mentioned in Gen 15:18 and it was a sign (enacted through a sacrifice) to confirm the promise given in Gen 15:7. In Gen 17, God further describes the covenant, emphasising (with 9x repetition) that it is " $m y$ covenant." God is the initiator who unilaterally draws up the terms. The benefits to Abram are repeated to include many descendants and land, with the additional promise "to be God to you" (17:7b, 8d). In return, the people are required to "walk before [God] . . . be "blameless" (17:1c) and "keep [God's] covenant" (17:9). James ${ }^{15}$ sums up the terms of the covenant in "I will be your God and you will be my people" and notes that this implies family-type commitment rather than a clearly defined contract or business arrangement. Clearly, the relationship is reciprocal and involves broad promises (which are central to the topic of this article).

Eade $^{16}$ maintains that promises are essentially commitments to a relationship rather than to a specific action. ${ }^{17}$ However, promises can change the nature of a relationship_-making a promise can make it stronger but not fulfilling

15 Peter G. James, "Promises to Keep," Sermons from Vienna Presbyterian Church (29 January 2012): 4.

16 Caroline Eade, "Promises, Promises," Cambridge Papers towards a Biblical Mind 16/4 (2007), [cited 2 April 2021]. Online: https://www.jubilee-centre.org/cambridgepapers/promises-promises-by-caroline-eade.

17 David R. Schmitt, "The Invocation of Moral Obligation," Sociometry 27 (1964): 299-310, notes that an important function of norms (and the covenant could be considered a "norm" in that it establishes the standards of relating between God and God's people) is to protect the rights of the weak and the power of the agreement lies in the norm itself (that is, the desire to be in relationship). 
a promise can threaten the relationship. In this article, we consider the situation where the psalmist makes a promise (thereby seeking to strengthen the relationship) and the situation where God does not seem to be fulfilling God's promise "to be your God," as established in the covenant. Most recognise that the covenant is based on God's faithfulness rather than the people's faithfulness in performing its obligations; ${ }^{18}$ but how should people interpret the situation when it is God who seems to fail to keep the obligations? For example, in Ps 137 those returning from the Babylonian exile "give voice to the full intensity of their emotions of vengeance and bitterness" particularly seeing the temple still in ruins. ${ }^{19}$ How could God allow this? How could God seemingly fail to protect the covenant people from the violations of pagan enemies?

There are several hypotheses as to the possible motivation of God when God does not appear to respond to the psalmist's plea. Some might say that God has a higher purpose in mind for the psalmist's benefit (e.g., "refining" or "strengthening" the psalmist). However, following legal thinking, to change the terms of an agreement for the other's benefit would suggest that the more powerful partner is acting out of "paternalistic motives" particularly when the other does not agree to this change. ${ }^{20}$ In modern society, the motive of paternalism is never acknowledged as a valid motive for changing rules of an agreement but the covenant in this case was established in a society with a different worldview. Moreover, paternalism is recognised by rhetoricians to show the restraint of power, not as a means to exploit the subordinate's weakness. ${ }^{21}$ Kant also observes that such a rhetoric may serve to elevate the hearer's understanding of himself, gaining the perception of a new identity. This could be the case in lament psalms if one considers that God's silence in response to the psalmist's plea is a form of rhetoric, enabling the psalmist to form a new view of himself in relation to God and a new understanding of God. ${ }^{22}$

Wolterstorff ${ }^{23}$ asserts that the covenant is God's way of bringing people into the fullness of shalom (or flourishing). The covenant and the enactment of

18 Deuteronomy 30:11-14 indicates that it is possible for people to keep the covenant, but ability does not imply obedience.

19 Leonard P. Mare, "Psalm 137: Exile - Not the Time for Singing the Lord's Song," OTE 23/1 (2010): 119.

20 Duncan Kennedy, "Distributive and Paternalist Motives in Contract and Tort Law, with Special Reference to Compulsory Terms and Unequal Bargaining Power," Maryland Law Review 41/4 (1982): 570-572, 590.

21 John Poulakos, "Review of Scott R. Stroud, Kant and the Promise of Rhetoric," KSO (2016): 44-45.

22 God's silence and inactivity could enable the psalmist to fully express his pain without interruption; Kathleen M. O'Connor, Lamentations and the Tears of the World (Maryknoll: Orbis Books, 2002), 85-86.

23 Nicholas Wolterstorff, "Justice as a Condition of Authentic Liturgy," Theology Today 48/1 (1991): 14-16. 
its terms must thus be seen through the lens of "God's bigger purpose." This does seem to suggest paternalism but in the God-humanity relationship, clearly, God is the father figure (pater). Nevertheless, as the next section shows, God welcomes lament prayer. Is lament then a means to change the attitude of the lamenter or the attitude of God? Saliers ${ }^{24}$ addresses these two possibilities when he asks: "Will our cries force God into action? Or does the very vehemence of complaint and lament bring about a deeper recognition that God has heard in the past and will hear again?"

Clearly, lament includes a challenge to God's fidelity and sovereignty. ${ }^{25}$ This has implications as we consider whether the underlying cause of some lament psalms is that God has not fulfilled God's side of the covenant. Brueggemann ${ }^{26}$ considers that lament challenges YHWH to "re-characterise," thus questioning "YHWH's sovereign freedom to be whom YHWH wants to be."

A further element to consider is that the shame of Israel is strongly linked with YHWH's name and reputation (particularly in the communal psalms of lament associated with the exile). In this sense, YHWH must "re-characterise" if YHWH is to be seen as honoured among the nations.

Before being able to determine if lament brings about change in the psalmist, God or both, various other factors need to be considered. Next, we look at how vows have been used for religious purposes (particularly in psalms of lament).

\section{Vow of (future) praise in psalms of lament}

It is worth noting that vows were and are part of the prayers of many communities seeking to get their deity to act in their interests. For example, the Romans had an ancient tradition that a vow should accompany a request. ${ }^{27}$ Usually, a gift to the deity (e.g., a new temple) would be promised, on condition that the request was granted. The vow of praise is also found in Babylonian and Egyptian psalms and even in primitive prayers such as that of the Khoi-khoi. ${ }^{28}$

24 D. E. Saliers, "Psalms in Our Lamentable World," Yale Journal of Music \& Religion 1 (2015): 108.

25 Brueggemann, "Lament as Wake-up Call," 227.

26 Brueggemann, Old Testament Theology: Essays on Structure, 29.

27 Frances H. Hahn, "Performing the Sacred: Prayers and Hymns," in A Companion to Roman Religion (ed. J. Rupke; Oxford: Blackwell Publishing, 2007), 235-236.

28 Claus Westermann, Praise and Lament in the Psalms (Louisville: John Knox Press, 1981), 76 . 
In addition, throughout Palestine today, the making of (conditional) vows at shrines is widespread. ${ }^{29}$

Monastic vows are also of interest. According to Anselm, a person takes such a vow in response to the promises of Christ with the expectation that if he "gives everything he is to God, [he will] receive from him whatever he needs." 30 In many ways, those in covenant with YHWH would have the same expectation, for surely this is the essence of "I will be your God and you will be my people"? The psalmist, as a member of the covenant people of God, expects his needs (including the need for protection) to be met by God. When this does not seem to happen and God is unresponsive to his pleas, he cries out in lament.

Biblical lament generally includes five elements-address to God, complaint, petition, affirmation of faith and a vow ${ }^{31}$ of (future) praise. The vow is usually at the end of the psalm although it may be repeated various times throughout the poem. There is often a sudden change of mood before a vow. Indeed, laments show many mood swings (e.g., from complaint to thanksgiving), usually marked by a waw adversative ('but' ${ }^{32}$ ), suggesting that help has been experienced or, for some reason, the psalmist has assurance that help will come.

There are various explanations as to what produces this change of mood in the psalmist. Westermann ${ }^{33}$ suggests that the psalmist "glance[s] beyond the present situation," senses God has intervened, and thus gives thanks or promises future praise (even before the deliverance) ${ }^{34}$. Another possible motive for the sudden change of mood has been posited as the result of an "oracle of salvation." More recently, two other explanations have come to the fore that see the sudden change as "emotion regulation" or as part of a "hidden transcript." These possibilities will be explored in the next section.

3a Possible reasons for the change of mood before the vow

In the worship-liturgy of Israel, there was a focus on remembering God's past miraculous deeds particularly the exodus experience (Exod 2-15). Israel

29 Salah H. Al-Houdalieh, "Visitation and Making Vows at the Shrine of Shaykh Shihb Al-Di- N," Journal of Islamic Studies 21/1 (2010): 379-384.

30 John Bayer, (O. Cist.), "Living toto corde: Monastic Vows and the Knowledge of God," Religions 10/424 (2019): 8.

31 The "vow" was originally to offer sacrifice but later became a vow to praise God's character thus indicating a desire to be in relationship with God; Westermann, Praise and Lament, 79.

32 For a different view, see Richard C. Steiner, "Does the Biblical Hebrew Conjunction - ו Have Many Meanings, One Meaning, or No Meaning at All?” Journal of Biblical Literature 119/2 (2000): 249-267.

33 Westermann, Praise and Lament, 73-75, 80-81.

34 This pattern is also seen in the Babylonian laments; Hermann Gunkel, The Psalms (Philadelphia: Fortress Press, 1967), 36. 
understood her history and faith as comprising experiences of lament followed by an "oracle of salvation" 35 and thus thanksgiving. ${ }^{36}$ Some scholars ${ }^{37}$ apply the same formula to lament psalms, suggesting that YHWH assures the psalmist in distress that his cry has been heard. However, when there is no apparent response from God, one option available to the psalmist is to continue the argument, hoping that YHWH "might yet be cajoled, flattered, shamed, or threatened into acting in deliverance." 38

Most commentators ${ }^{39}$ view the reference in lament psalms to YHWH's past deeds as emphasising the contrast between the past glory and the woeful present. By making such a startling contrast, the psalmist introduces a "deep tension," ${ }^{40}$ which aims to prod God into action. ${ }^{41}$ Support for this idea is that such historical flashbacks are only included in those lament psalms where the psalmist's problem is with God. ${ }^{42}$ Thus the psalmist's motivation is not to praise God but rather to stir God to act in accordance with what God's conduct could/should be in terms of the covenant. ${ }^{43}$

For decades, many scholars have noted this notion of the psalmist seeking to urge God into action. Gunkel and Begrich claim that the psalmist "strives to move the heart of God with everything he says." 44 However, Flesher ${ }^{45}$ asks, "Are the laments [only] evidence of attempts to change the heart of God, or are they

35 Artur Weiser, The Psalms (trans. H. Hartwell; OTL. London: SCM, 1962), 80, 149152. Cf. also D.A. Bosworth, "House of Weeping: The Motif of Tears in Akkadian and Hebrew Prayers" (ANE Monographs 24; Atlanta: SBL, 2019), 20.

36 James Plastaras, The God of Exodus (Milwaukee: Bruce Publishing Co, 1966), 4959.

37 See, for example, Michael Neary, "The Importance of Lament in the God/Man Relationship in Ancient Israel," The Irish Theological Quarterly 52/3 (1986): 182-186.

38 Jon D. Levenson, Creation and the Persistence of Evil (Princeton: Princeton University Press, 1994), XVLLL.

39 E.g., Craig C. Broyles, The Conflict of Faith and Experience in the Psalms. A FormCritical and Theological Study (Sheffield: JSOT Press, 1989), 42, 51.

40 Bujorel Lucaci, "YHWH's Absence or Hostility as Two Main Motifs of Suffering and Protest in Lament Psalms: A Theo-dramatic Approach," (MA thesis, Melbourne College of Divinity), 2011, 54.

41 Broyles, The Conflict of Faith and Experience, 220.

42 Ibid., 42-43. The exception is Ps 83 where it simply adds dramatic effect to the petition.

43 Lucaci, "YHWH's Absence or Hostility," 108.

44 Hermann Gunkel and J. Begrich, Introduction to Psalms: The Genres of the Religious Lyric of Israel (Mercer University Press, 1998), 169-170.

45 LeAnn S. Flesher, "Rapid Change of Mood: Oracles of Salvation, Certainty of a Hearing, or Rhetorical Play?" in "My Words Are Lovely": Studies in the Rhetoric of the Psalms (ed. Robert L. Foster and David M. Howard Jr; New York: T\&T Clark, 2008), 35 . 
[also] evidence of a shift in mood on the part of the psalmist?" Bosworth ${ }^{46}$ claims $^{\circ}$ that these are not mutually exclusive possibilities but that the change of mood may reflect/create an emotional shift in the psalmist (as part of "emotion regulation") or may be understood as a rhetorical device designed to move YHWH (using a "hidden transcript"). These two possibilities are discussed next.

(i) Emotion regulation: Bosworth ${ }^{47}$ argues that all laments view God as an "emotion regulation partner." As the psalmist shares his emotions with YHWH, the relationship between them is strengthened. There are two elements to what happens. First, the psalmist shares his pain (as motivation for God to empathise and help). In line with Trauma Theory, this is an initial step in his healing, becoming an agent and giving his version of what happened. ${ }^{48}$ Empathy Theory also suggests that even simple reminders of one's values may be enough to call upon the other (in this case, God) to affirm [God's] sense of self ${ }^{49}$ and maintain [God's] own perceived worth and integrity. ${ }^{50}$ Whether this precept can be extended from humans to deity is questionable but it raises a possibility.

The second element at play when the psalmist shares his emotions with God relates to the "inner voice," which people often use to regulate their emotions. ${ }^{51}$ This refers to the silent discourse that takes place in the mind as seen in Ps 103:1 ("Bless the LORD, o my soul"). Bosworth ${ }^{52}$ maintains that the inner voice originates in the social environment, arising from various sources (such as the words of religious leaders, liturgies, parental instruction and scriptural texts). The inner voice may appear to represent the voice of the deity or state what the deity thinks or feels.

Since the inner voice derives from the social environment, the internal psychological explanation and the external liturgical explanation (of a divine oracle) are not mutually exclusive. The "voice of God" (or divine oracle) may include some involvement from a wider human community. ${ }^{53}$

46 Bosworth, "House of Weeping," 95-96.

47 Bosworth, "House of Weeping," 5, 12.

48 Judith L. Herman, Trauma and Recovery. The Aftermath of Violence: From Domestic Abuse to Political Terror (New York: Basic Books, 1992), 155.

49 Sarah Kim and Ann L. McGill, "Helping Others by First Affirming the Self: When Self-Affirmation Reduces Ego-defensive Downplaying of Others' Misfortunes," Personality and Social Psychology Bulletin 44/3 (2018): 346.

50 Claude M. Steele, "The Psychology of Self-affirmation: Sustaining the Integrity of the Self," Advances in Experimental Social Psychology 21 (1988): 261-302.

51 Charles Fernyhough, The Voices Within: The History and Science of How We Talk to Ourselves (New York: Basic, 2016), 49.

52 Bosworth, "House of Weeping," 15-17.

53 Ibid., 93, 95. 
(ii) Hidden transcript: $\operatorname{Scott}^{54}$ maintains that the discourse of subordinates before their superiors typically includes elements of ritualised performance (the "public transcript") but also a "hidden transcript" with elements of resistance. For example, in the book of Lamentations, the communal lament (ch.5) comprises the public transcript but there is also a hidden transcript nurtured by the anger and frustration of the people. ${ }^{55}$ The hidden transcript is seen in the way that Lam 5 deviates from the usual form of a communal lament or a typical city lament. 56 In particular, it is possible to identify "covert elements" (e.g., contradictory statements, reminders of promises made but not upheld and the use of double entendre), as noted by a number of scholars. ${ }^{57}$ These hidden elements suggest another agenda at work, one which enables Israel to reclaim her dignity and have "a viable future with YHWH."58

In the lament psalms, the vow of (future) praise may be part of a hidden transcript, giving the impression that the psalmist is on the side of God when in fact he is actually giving criticism or at least seeking to goad God into action. The next section sheds light on persuasive tactics and the way persuasion works. Thereafter, the text of some lament psalms is scrutinised for any possible "covert elements" suggesting a hidden agenda.

\section{PSYCHOLOGICAL PRINCIPLES OF PERSUASION (UNDERLYING "THE HIDDEN TRANSCRIPT")}

A number of related terms fall into the semantic domain of someone "trying to get God to act" but differences do occur. Thus, some definitions are in order.

\section{Terms}

1a Manipulation

Manipulation is illegitimate domination, by means of discourse, which insists (erroneously) that the manipulator is acting in the best interest of the dominated person. The recipient is a victim with a passive role. Manipulators use several

54 Scott, Domination and the Arts of Resistance.

55 Williamson, "Lament and the Arts of Resistance," 72-73; Scott, Domination and the Arts of Resistance, 111, 113.

56 Williamson, "Lament and the Arts of Resistance," 74, 79-80.

57 See, for example, Iain Provan, The New Century Bible Commentary. Lamentations (Grand Rapids: Eerdmans, 1991), 127; Williamson, "Lament and the Arts of Resistance," 75-78.

58 Scott, Domination and the Arts of Resistance, 214-215. 
tactics, including coercion and influence ${ }^{59}$ and there is not always a clear distinction between (illegitimate) manipulation and (legitimate) persuasion. ${ }^{60}$

$1 b$ (Self-)deception

Self-deception is a defensive response to difficulties ${ }^{61}$ and is not always a means to deceive another. ${ }^{62}$ If a person feels "disconnected from one's future self," he/she may lie or make a false promise. ${ }^{63}$ People frequently lie to those on whom they are dependent for resources that might otherwise be withheld. ${ }^{64}$

Self-deception may enter into lament psalms in that the psalmist may express confidence in God (a controlled process) when he actually feels anger against God (an automatic process). The self-deception enables the psalmist to pursue the goal of getting God to act while simultaneously retaining the hidden goal of challenging God's power in the situation. ${ }^{65}$ The psalmist's attempt to "get God to act" may be an unconscious response to his need to regain a sense of control, ${ }^{66}$ necessary for psychological and physical health. ${ }^{67}$ When a person feels out of control, belief in a controlling God can meet the need for a sense of control. ${ }^{68}$

59 David M. Buss, Mary Gomes, Dolly S. Higgins and Karen Lauterbach, "Tactics of Manipulation," Journal of Personality and Social Psychology 52/6 (1987): 1219-1220.

60 Teun A. Van Dijk, "Discourse and Manipulation," Discourse and Society 17/3 (2006): 359-361.

61 William Von Hippel and Robert Trivers, "The Evolution and Psychology of Selfdeception," Behavioural and Brain Sciences 34 (2011): 12.

62 Louisa C. Egan, "Self-deception Is Adaptive in Itself," Behavioural and Brain Sciences 34/1 (2011): 19.

63 Hal E. Hershfield, Taya R. Cohen and Leigh Thompson, "Short Horizons and Tempting Situations: Lack of Continuity to Our Future Selves Leads to Unethical Decision Making and Behavior," Advances in Consumer Research 40 (2012): 22-27. https://www.acrwebsite.org/volumes/v40/acr_v40_13180.pdf.

64 Wolfgang Steinel and Carsten K.W. De Dreu, "Social Motives and Strategic Misrepresentation in Social Decision Making," Journal of Personality \& Social Psychology 86 (2004): 419-434.

65 Von Hippel and Trivers, "The Evolution and Psychology of Self-deception," 7.

66 Jennifer A. Whitson and Adam D. Galinsky, "Lacking Control Increases Illusory Pattern Perception," Science 322 (2008): 115.

67 Sheldon Cohen, Behavior, Health, and Environmental Stress (New York: Plenum Press, 1986).

68 Aaron C. Kay, Danielle Gaucher, Jaime L. Napier, Mitchell J. Callan and Kristin Laurin, "God and Government: Testing a Compensatory Control Explanation for the Support of External Systems," Journal of Personality and Social Psychology 95 (2008): $18-35$. 


\section{1c Coercion and influence}

Coercion and influence are matters of degree and both are present to some extent in almost every encounter of cooperation and conflict. ${ }^{69}$

\section{1d Persuasion}

Persuasion is a skill used to try to make others perform certain actions. ${ }^{70}$ Towards this end, the persuader must change the other person's beliefs ${ }^{71}$ by using discourse to modify the other's intentions.

A persuasive appeal must include a motivation, either a promise of reward or a threat of deprivation. ${ }^{72}$ Lament psalms often include reference to rewards ("If you grant the request, I will reward you") or the suggestion of a "deprivation" (e.g., loss of status), if God does not meet the covenant obligations. In the human situation, a person may be reminded of his morality by affirming him for his important values or previous positive behaviours. ${ }^{73}$ The question is whether God can be similarly influenced.

\section{1e Promises}

Promises are central to this discussion and form the basis of Persuasion Theory, which is discussed next. Persuasion Theory is based on mathematical models, as the definition below indicates:

A promise is a speech act consisting of a declaration by the speaker $x$ of the intention to perform a certain action $a x$, under the condition that $a x$ is something wanted by the hearer $y$, thereby entering into an obligation to do $a x .^{74}$

69 John S. Odell, "Negotiation and Bargaining," in Handbook of International Relations ( $2^{\text {nd }}$ ed.; ed. W. Carlsnaes, T. Risse and B. Simmons; Thousand Oaks: Sage Publications, 2012), 3.

70 Chaïm Perelman and L. Olbrechts-Tyteca, The New Rhetoric: A Treatise on Argumentation (Dame: Notre Dame Press, 1969).

71 Cristiano Castelfranchi, "Reasons: Beliefs Structure and Goal Dynamics," Mathware \& Soft Computing 3/2 (1996): 233-247.

72 Elihu Katz, Michael Gurevitch, Brenda Danet and Tsiyona Peled, "Petitions and Prayers: An Analysis of Persuasive Appeals," (2008): 269 [cited 22 January 2021]. Online:

https://in.sagepub.com/sites/default/files/upm-

assets/23163_book_item_23163.pdf.

The essay is based on Elihu Katz, "Petitions and Prayers: A Method for the Content Analysis of Persuasive Appeals," Social Forces 47 (1969): 447-463.

73 Von Hippel and Trivers, "The Evolution and Psychology of Self-deception," 7.

74 John Searle, Speech Acts (Cambridge, UK: Cambridge University Press, 1969). Cf. John L. Austin, How to Do Things with Words (2 ${ }^{\text {nd }}$ ed.; Oxford: Clarendon Press, 1975). In the rest of the essay and for the sake of clarity, I will use "psalmist" and "God" where 
Applying the theory by Castelfranchi and Guerini ${ }^{75}$ to psalms, a "promise" means that the psalmist takes responsibility to be truthful about what he is declaring to God concerning a future action (to praise God) that is presupposed to be under his control and which favours God and in which God is interested. As the promised action is in the future, the hearer must decide whether or not to trust the speaker. Deverell ${ }^{76}$ notes that "A promise is only a promise if it becomes an event." If a promise is to be effective and to persuade the hearer, the speaker must create a strong link between his promise and future action. ${ }^{77}$

\section{Persuasion Theory (with a focus on "promises")}

The work of Castelfranchi and Guerini, 78 based on the "Beliefs, Desires, Intentions model," 79 is particularly helpful in trying to understand the mechanics at play when the psalmist makes a promise to God. They assert (p.1) that not all promises (or threats) are for persuasion nor are all conditional, although their focus is on those which are intended to have a persuasive impact. ${ }^{80}$ These are incentive-based actions, rooted in dependence and power relations. The promise is always and necessarily (although not openly) accompanied and supported by a threat.

Persuasion Theory is based on the following premises, when applied to psalms of lament:

\section{2a Need for persuasion}

The psalmist assumes he must do something to induce God to intervene. It is understood that God is not already intervening and has put up some barriers against doing so. Persuasion seeks to find ways to overcome these barriers by

the model refers to $x$ and $y$, and "promise of praise" and "save/intervene" for the actions referred to by $a x$ and $a y$.

75 Cristiano Castelfranchi and Marco Guerini, "Is It a Promise or a Threat?" Pragmatics and Cognition (2007): 3 [cited on 13 March 2021]. Online: https://www.researchgate.net/publication/233583284.

76 Garry J. Deverell, "If It Be Your Will: Making Promises with Derrida, Ricoeur and Chauvet," Pacifica: Australasian Theological Studies 16/3 (2003): 271-294. Eade, C. "Promises, Promises."

77 Robert P. Abelson and David E. Kanouse, "Subjective Acceptance of Verbal Generalizations," in Cognitive Consistency (ed. S. Feldman; New York: Academic Press, 1966), 171-197.

78 Castelfranchi and Guerini, "Is It a Promise or a Threat?" Citations to their work are my original deductions from and applications of their model.

79 Philip R. Cohen and Hector Levesque, "Persistence, Intention, and Commitment," in Intentions in Communication (ed. Philip R. Cohen, Jerry Morgan and Martha E. Pollack; Boston: MIT Press, 1990).

${ }^{80}$ Castelfranchi and Guerini, "Is It a Promise or a Threat?," 1. 
conveying appropriate beliefs to God's way of thinking. ${ }^{81}$ There are two situations: a) God must be persuaded to intervene when God did not intend to do so; or b) God must be persuaded to intervene when God intended not to do so. ${ }^{82}$ In the latter case, there is more resistance (and thus persuasion is more difficult) as it implies that God has reasons/beliefs for not acting, which must first be overcome. Only then can an attempt be made to persuade God to take on the new intention-to intervene.

The psalmist's goal must thus move through three levels. ${ }^{83}$ First, he must get God to believe him when he says he will praise God. Second, this must induce in God an intention to act. Third, God must act. To get from the second level to the third level, persuasion is needed.

$2 b$ Overt or implied condition in the vow

There are two influencing situations, one which is conditional and one which is not. ${ }^{84}$ In the first, the psalmist asserts that if God saves, then he will praise God. The condition is the psalmist's goal and expresses what God should "adopt" if the psalmist in turn is to adopt God's goal (to be praised). The psalmist needs to create a link between his action (future praise) and God's required action (to save). The second situation (without an overt conditional statement) still intends to influence God but the condition is implicit. This may be because it is expected to be obvious from the context or because the psalmist thinks that if the condition is overtly expressed, God will not act. The psalmist intends to elicit action from God but not as a 'negotiated' counterpart of his own action. Rather, he hopes that God will remember God's part in the covenant (as clarified in the next principle).

2c Social commitment in a promise-relationship

When the psalmist makes a promise (or vow), he commits himself to an interpersonal obligation. Thus, if God accepts this arrangement, God has some rights. Even if the psalmist is not sincere, the obligation must be carried out. Moreover, a promise results in God having a social commitment towards the psalmist; for if God accepts the arrangement, God must act. ${ }^{85}$

$2 \mathrm{~d}$ Relation between promise and request

An influencing promise consists of a link between two linguistic acts, viz. a promise of future praise and a request for God's intervention. The promise is

81 Castelfranchi and Guerini, "Is it a Promise or a Threat?" 9.

82 Ibid., 10.

83 Ibid., 156.

84 Ibid., 12-15.

85 Marco Guerini and Cristiano Castelfranchi, "Promises and Threats in Persuasion," Computational Models of Natural Argument VI (2006): 15, 20 [cited on 10 March 2021]. Online: http://cmna.csc.liv.ac.uk/CMNA6/CMNA06Guerini.pdf. 
conditional to the request, ${ }^{86}$ even if not explicitly expressed. Once the psalmist has identified the benefit accruing to God (as revealed in his promise), God is more likely to be persuaded to respond to the request. ${ }^{87}$

\section{2e A promise must be credible and convincing}

It is crucial that God believes that the psalmist is able to provide the positive favour (praise). In a sense then, the psalmist has some power over God, viz. the power of providing incentives, in that God depends on the psalmist to receive praise. Just as the psalmist can help God achieve God's goal (of being praised), the psalmist can also jeopardise this goal. If God's goal has a higher value for God than the cost of God's action (intervening and saving the psalmist), then, the psalmist can threaten God to jeopardise the goal, if God does not intervene. On the other hand (from the psalmist's view), the cost of the promised action (giving praise) must be less than the value resulting from God's intervention. "Threatening God" may seem absurd, but there is no promise without a threat, ${ }^{88}$ even if implied.

\section{$2 \mathrm{f}$ Other strategies to incentivise God to act}

The force of any rhetorical argument depends on the speaker's social status relative to the hearer. ${ }^{89}$ Thus, the inequality of the power dynamic between God and the psalmist is a significant factor in the success or otherwise of the psalmist's rhetoric. However, Zartman and Rubin ${ }^{90}$ show that equal power is not necessary for effective negotiation. Weaker parties are able to use other relationships and strategies to mitigate their power disadvantage. For example, apart from his own praise, the psalmist can also imply that, when others hear his praise and testimony of God's saving act, these other people are also likely to praise God. This latter outcome is under his control (directly or indirectly) and will not happen without his action. ${ }^{91}$ However, it is necessary that the psalmist make God aware of this additional benefit ${ }^{92}$ for it to serve as an extra incentive. A further strategy the psalmist can use is to "frame public opinion." 93 He can do this by drawing in other witnesses to the conversation, thus, impacting God's reputation (in that many others will know of God's response). Again, it is

\footnotetext{
86 Guerini and Castelfranchi, "Promises and Threats," 17.

87 Odell, "Negotiation and Bargaining," 17.

88 Guerini and Castelfranchi, "Promises and Threats," 18-19.

89 J.A. Levytska, "Argument as a Way of Persuasion" (Yaroslav the Wise National Law University; 2015) [cited 23 January 2021]. Online: http://molodyvcheny.in.ua/files/conf/fil/06may2015/06may2015.pdf\#page=106.

90 I.W. Zartman and J.Z. Rubin. 2000. Power and Negotiation (Ann Arbor: University of Michigan Press, 2000).

91 Guerini and Castelfranchi, "Promises and Threats," 17-18.

92 Katz et al, "Petitions and Prayers," 275-277.

93 Odell, "Negotiating from Weakness," 4-5.
} 
necessary that the psalmist make God aware of this threat ${ }^{94}$ As another incentive, it may also be possible to question whether praising God is part of the original covenant arrangement or it is an additional incentive that the psalmist can offer.

$2 \mathrm{~g}$ Openness

Persuasion depends on first "opening minds to flexible information processing." "95 It may be obvious that God knows the mind of the psalmist but the fact that the latter is willing to keep working at the relationship (even suggesting an alternative strategy, the offer of praise, to overcome the impasse) adds weight to God's perception that the psalmist is committed.

According to Odell, ${ }^{96}$ even mildly positive affect in the speaker will lead to an improved outcome. The fact that the psalmist does not simply abandon the relationship shows such positive affect on his part. Thus, it can be assumed that the psalmist's commitment to the relationship would make God more open to respond positively.

2h God's altruism.

The rhetoric of persuasion may also include appeals to commonly held social norms operating on the other, resulting in a person responding based on a sense of moral obligation. ${ }^{97}$ For example, the psalmist usually appeals not only to the covenant but also to God's altruism (the stronger helping the weaker). ${ }^{98}$

In the next section, five psalms are reviewed which contain vows of future praise. The vows are analysed in terms of the theory delineated in sections 2 and 3 , to identify "covert elements" that might play into the hidden transcript.

94 Katz et al, "Petitions and Prayers," 275-277.

95 Shelly L. Chaiken, Deborah H. Gruenfeld and Charles M. Judd, "Persuasion in Negotiations and Conflict Situations," in The Handbook of Conflict Resolution: Theory and Practice (ed. Morton Deutsch and Peter T. Coleman; San Francisco: Jossey-Bass Publishers, 2000).

96 Odell, "Negotiation and Bargaining," 18.

97 Katz et al, "Petitions and Prayers," 270.

98 Empirical evidence, for example, John Schopler and Nicholas Bateson, "The Power of Dependence," Journal of Personality and Social Psychology 2 (1965): 247-254), show that appeals to altruism are often effective, particularly when the person appealing is very dependent on the other, probably because the appeal awakens in the hearer a sense of obligation to help the weaker party. Berkowitz, Leonard and Louise R. Daniels, "Responsibility and Dependency," Journal of Abnormal and Social Psychology 2 (1965): 247-254. 


\section{EXAMPLES OF VOWS IN SOME BIBLICAL LAMENTS}

\section{$1 \quad$ Psalm 13}

Weber ${ }^{99}$ notes that Ps 13 has a "simultaneity" of praise (e.g., v.5) and lament (e.g., v.1). The mood of complaint (vv.1-4) suddenly changes to one of trust (v.5) and includes a promise to praise (v.6a) as well as a reason for praise. ${ }^{100}$ The promise does not appear to be conditional, although the inclusion of three "lest" clauses (vv.3b, 4a, 4b) hints that there might be a "lest" connected with the reward for God in v.6a.

The aspect of the verbs suggests that the trust (vv.5a, 6b) is in the past (completed action) and the praise (vv.5b, 6a) is future-oriented (the verbs being incomplete). Thus, the praise is not performative and thus not a certain reality.

To try to change God's way of thinking, the psalmist: a) expresses his deep pain (vv.1-4), appealing to God's altruism as well as God's responsibility to meet his needs (as per the covenant) and b) identifies the benefit God will receive, if God acts (v.5a). Although part of this benefit is that God will be praised by the psalmist, it also will increase God's status before the enemies (who claim victory over God's person, in v.4). This idea of using the threat of shame as a motivation for God to act is clearly articulated in the next psalm (Ps 14) when the psalmist notes that God's enemies are denying God's existence (v.1) and are "eating up YHWH's people." Thus, YHWH should "restore the fortunes of his people" (v.7b), linking their shame (and YHWH's shame) with the exile.

\section{$2 \quad$ Psalm 22}

Psalm 22 comprises two major sections-a lament section (vv. 2-22) and a praise section (vv. 23-32). Within the lament, David recalls his past experience with God (vv.4-6, 10-12), with the goal of goading God to intervene. ${ }^{101}$ He uses vivid language to describe his extreme suffering, ending with four heart-rending appeals (vv.19-21), as he seeks to "convince God" and "persuade God to act on [his] behalf." ${ }^{102}$ To "convince God" implies a change in God's beliefs about him

99 Beat Weber, "Zum sogenannten 'Stimmungschwung' in Psalm 13," in The Book of Psalms: Composition and Reception (ed. P.W. Flint and P.D. Miller; Leiden: Brill, 2005), 133.

100 Westermann, Praise and Lament in the Psalms, 75-78.

101 Stephen P. Ahearne-Kroll, "Challenging the Divine: LXX Psalm 21 in the Passion Narrative of the Gospel of Mark," (2006), 119-148 [cited 23 July 2020]. Online: https://www.academia.edu/9393723/Challenging the Divine_LXX_Psalm_22 in the Passion_Narrative_of the_Gospel_of_Mark.

102 Ahearne-Kroll, "Challenging the Divine," 130-131. 
(the second level of the psalmist's goal) and to "persuade God to $a c t$ " achieves the third level of the psalmist's goal. Part of the latter (persuading God to act) is calling upon YHWH's reputation (e.g., vv.8, 22, 27).

Some scholars explain the sudden change of mood (between v.21a and v.21b) as the result of a divine oracle but there is no direct evidence for such a conclusion in ancient Israelite liturgy. ${ }^{103}$ Nevertheless, Ps 22 can be read as a rhetorical whole if the praise is understood as promised praise rather than actual praise. This is supported by the fact that the verbs in the praise-section of the poem (vv.22, 25-31) are future-oriented. The possibility of future praise adds to the persuasive rhetoric, implying an assumed conditional before v.22: "If you answer me, I will tell of your name to my brothers..." 104 The promised praise is particularly persuasive in its effect as God is referred to as "the praise of Israel" (v.3). Thus, "if David is saved, then God will get what is due, namely the praise of Israel and the praise of all the nations." 105

However, the aspect of the verb in v.21b (present perfect, implying a completed action) suggests that, at that point in the psalm (before the praisesection), the psalmist already senses that he has been delivered. Clearly, something significant has happened in his thinking and the psychological notion of an "inner voice" could be helpful in explaining this sudden change of mood, which leads to the declaration of a "serious vow."106

Further incentives for God to respond are apparent in that the psalmist frames his praise-reward in the public domain (v.22), thus, enhancing God's reputation. Furthermore, he increases the number of those who will give God praise by calling upon all the nation to praise God (v.23), which as a king, he has authority to promise. ${ }^{107}$

\section{$3 \quad$ Psalm 88}

Psalm 88 is considered "the darkest psalm," full of desperate petitions for God to act. However, unlike most personal lament psalms, there is no vow of future praise. Instead, the psalmist seeks to motivate God's intervention by reminding God of the covenant relationship between them. In the midst of his pain (v.11), he recalls God's hesed ('steadfast love'). As Stoebe ${ }^{108}$ notes, this reminds God of the promises inherent in the covenant. Similarly, 'faithfulness,' 'wonders,'

103 Ibid., 127-128. The verb used for 'answer' in Ps 22:21b is the same as that used in 1 Sam 28:6, 15 where it refers to "answering by oracle." However, in 1 Sam 7:9, the same verb implies "answering by action." Moreover, repeatedly in the Psalms, this verb means "answer by action," for example, $3: 4 ; 4: 1 ; 20: 1$ (in all, 77x).

104 Ibid., 129-130.

105 Ibid., 132.

106 Lucaci, "YHWH's Absence or Hostility," 87-88.

107 Ahearne-Kroll, "Challenging the Divine," 132-133.

108 H.J. Stoebe, Tסח, TLOT (Vol. 2; Peabody: Hendrickson, 1997), 451. 
and 'righteousness' (vv.11b-12) remind God of God's character and of the reputation to be maintained.

One distinctive feature of this psalm is the close "I-you" relationship that is expressed in almost every verse. The 1PS form "I" is used in 7 verses and the 2PS "you" in 11 verses, and apart from the last verse, there is no reference to a third party. Even then, the third party is mentioned as part of the problem that YHWH has caused for the psalmist (not as possible praise-givers, as in many lament psalms). Again, unlike other lament psalms which describe God's savingaction in the past, this poem is only concerned with the present (or God's actions in the past which have put the psalmist in the terrible "present" he faces). There is no hint of praise. Only six positive words enter into the conversation (vv.1012) and then, in the form of complaints (voiced as rhetorical questions), positive qualities that are not being experienced.

The only motivation the psalmist uses to get God to act is a reminder of who God is ("God of my salvation" and $Y H W H$, the name linked with the covenant, v.1) and an ongoing repetition of his plea for help (vv.9b-c, 13). Perhaps he hopes to wear down God's resistance by his ceaseless petitioning ("every day," v.9b). As the rest of the verses (vv.3-9a, 14-18) are all complaints against God, it is unlikely he is appealing to God's altruism. His only hope is God's character (particularly hesed) and the covenant-relationship between them.

\section{$4 \quad$ Psalm 35}

Psalm 35 is a communal lament. Most communal laments do not include a definite vow of praise, ${ }^{109}$ possibly, because they often end without resolution ${ }^{110}$ . However, Ps 35 does include a vow (v.28) and it is similar to most communal laments in that enemies play a significant role, shaming the people (and thereby $\mathrm{YHWH}^{111}$ ) unjustly (v.11). Indeed, in communal laments connected with the exile, the psalmist's major charge is that "the indignities of exile outweigh Israel's crimes." 112

109 Westermann, Praise and Lament in the Psalms, 60.

${ }^{110}$ Federico G. Villanueva, The 'Uncertainty of a Hearing': A Study of the Sudden Change of Mood in the Psalms of Lament (Leiden: Brill, 2008), 217.

111 Jerry Hwang, "'How Long Will My Glory Be Reproach?' Honour and Shame in Old Testament Lament Traditions," OTE 30/3 (2017): 689, argues that Gunkel and Begrich's (1998) emphasis on the individual lamenter's goal, which is "to obtain something from God," has overlooked the shame element in communal laments. The complaint is not just for the psalmist's benefit but also that YHWH's honour be restored.

112 Hwang, "How Long," 694-695. 
However, the psalmist's problem is also with YHWH in that YHWH is not helping. The psalmist complains in v.17 (with "a note of indignation") ${ }^{113}$ about this lack of intervention: "How long will you [just] look on?" It seems that the psalmist has been in distress for a long time. ${ }^{114}$ Clearly, he has appealed to YHWH many times, beginning in vv.1-8, continuing in v.17, and reaching a high point in verses 22b-26. Despite his criticism of YHWH as part of the problem, the poet sees his solution as lying in YHWH's character and in divine judgment. ${ }^{115}$

Motivation for God to act is based primarily on the fact that God is the psalmist's "partner in the covenant,"116 indeed "[the psalmist's] salvation" (v.3c). He also reminds God that he, the psalmist, is righteous (v.27), as is God (vv.24, 28), and thus they are on the same "team," both supporting justice. He also refers to his own weakness (v.10b) in contrast to God being a saviour (v.3b), the one to protect the helpless (v.10e). He thus calls upon God's compassion and altruism (as the strong partner to intervene on behalf of the weak).

Similarly, he uses very vivid language to describe the atrocities he has suffered (e.g., "malicious enemies" in v.11, "tore at me without ceasing" and "gnash at me with their teeth" in vv.15-16) in an attempt to provoke YHWH to feel pity for him and to punish those who did evil. In contrast, he reminds YHWH that his life is "precious" (v.17c) and that he showed compassion when his enemies were in trouble (vv.13-14). ${ }^{117}$ The enemies are depicted as behaving as if there is no God ("profane mockers" in v.16), and thus the psalmist considers he is "within the will of God" when he asks God to punish his enemies. 118 The imprecations he uses (vv.4-6, 8, 19, 25-26), are "among the most intense in the Psalter" but are framed in the sense of asking God to "allow the wicked acts of the enemies to destroy themselves." 119 As Poser notes, people who have experienced "unspeakable trauma" tend to use imagery at "the limits of

113 Walter Brueggemann, The Message of the Psalms (Minneapolis: Augsburg, 1984), 64.

114 Broyles, The Conflict of Faith and Experience, 193-194.

115 C. Hassel Bullock, Encountering the Book of Psalms (Grand Rapids: Baker Books, 2001), 143.

116 Brueggemann, The Message of the Psalms, 64.

117 Ibid.

${ }^{118}$ Othmar Keel, The Symbolism of the Biblical World: Ancient Near East Iconography and the Book of Psalms (New York: Seabury, 1978), 85. Cf. Erich Zenger, A God of Vengeance? Understanding the Psalms of Divine Wrath (Trans. L.M. Maloney; Louisville: Westminster John, 1996), 79.

119 Bullock, Encountering the Book of Psalms, 228, 234. 
language." 120 What is critical is that the psalmist puts justice into the hands of God, ${ }^{121}$ not seeking his own retaliation.

Apart from the psalmist's passionate language, he also tries to motivate God to act by making vows of future praise (vv.9, 10, 18, 28) and confessing trust in God (vv.10, 24). Whether the latter is genuine trust or part of the psalmist's "persuasive rhetoric" must be considered. However, it is noted that the psalmist's vows are made three times, at regular intervals. The first vow refers only to the psalmist's private praise of YHWH (vv.9-10) but this extends in v.18 to giving praise in the public domain (before "the great congregation"). There is further incentive in that the group of witnesses join in the praise of God (vv.27-28).

\section{$5 \quad$ Psalm 79}

Psalm 79 is also a communal lament which also (unusually) has a vow (in v.13). Westermann argues that the promised future praise is not conditional but an affirmation of ongoing trust. ${ }^{122}$ This is supported by the vow citing the covenant formula ("we your people"), suggesting that it is based on the relationship between the psalmist and YHWH (and not a condition being met). Nevertheless, the fact that the psalmist reminds God of the covenant between them implies that he is seeking to persuade God by his reminder. Moreover, the psalmist entwines YHWH's honour with that of the psalmist (e.g., vv.9, 12), appealing to YHWH's self-interest (a common ploy in lament psalms linked to the exile) ${ }^{123}$.

The psalmist uses various other strategies to encourage God to act. In verse 9c, he uses "confession of sin" to goad God into action. ${ }^{124}$ This is very unusual in lament psalms. In fact, Ps 79 is the only communal lament that includes a confession of sin. It may be that the psalmist is trying to show humility and contriteness before God, to win God's favour or it may not be a strategy to get God to act but simply a survival mechanism. As Frechette notes, blaming the self provides an explanation in a context of chaos and thus gives the psalmist a measure of control and psychological ease. ${ }^{125}$

${ }^{120}$ Ruth Poser, "No Words: The Book of Ezekiel as Trauma Literature and a Response to Exile," in Bible through the Lens of Trauma (ed. Elizabeth Boase and Christopher G. Frechette; Semeia Series 86; Atlanta: SBL Press, 2016), 45.

121 Zenger, A God of Vengeance? 79.

122 Westermann, Praise and Lament in the Psalms, 222.

${ }^{123}$ In later Jewish tradition, Ps 79 is recited on the 9th of Av, as is Ps 137, to commemorate the destruction of Jerusalem; Ulrich Kellerman, "Psalm 137," ZAW 90/1 (1978): 54.

124 Denise Dombkowski Hopkins, Psalms: Books 2-3 (Wisdom Commentary 21; Collegeville: Liturgical Press, 2016), 284.

125 Christopher G. Frechette, "Destroying the Internalized Perpetrator: A Healing Function of the Violent Language against Enemies in the Psalms," in Trauma and 
Nevertheless, incentives to motivate God's intervention are apparent in verses $9 \mathrm{~b}$ and 9d when the psalmist refers to God's glory and God's name (or reputation). ${ }^{126}$ In the final verse, the psalmist also frames the vow in the social context of the community ("we will give thanks") and increases the incentive of future praise by indicating that it will be "forever, from generation to generation" (vv.13b-c).

\section{E CONCLUSION}

A number of scholars hold to the traditional view (which supports the official theology) that the lamenting psalmist is not trying to manipulate God by making a vow of future praise. For example, Marrs asserts that "Manipulation [was] unnecessary, for... the relationship was rooted in [God's] integrity." 127 However, he does note, with reference to Ps 130 that "Israel cried to God, appealing to his reputation." Reminding God of God's reputation (as noted in many lament psalms, particularly those connected to the exile) does seem to be a persuasive move with the implied threat of a loss of status should God not fulfil what is expected of God. Westermann, too, never sees the vow as a way of convincing God to act. He claims that "It is totally false to belittle [the vow] as a bargain."128 However, persuasion theory suggests that the psalmist uses various rhetorical devices and tactics, including a vow of future praise with an implied condition that God will act.

Of the five psalms in this study, four of them appeal to God's altruism ${ }^{129}$ (through the psalmist's expression of his pain and God's ability to save) as well as to the covenant. Three (Pss 22, 35, 79) use the expectation of others also praising as an added incentive and two (Pss 22 and 35) frame public opinion (God's reputation before others) as an extra motivation. The one example that does not include a vow (Ps 88) shows the psalmist at his most desperate. In such a case, it appears that all he can do is appeal to the covenant and to God's compassion; in such extremity, with no strength for persuasive tactics, the only basis he has for salvation is his relationship with God and the character of his covenant-partner.

\footnotetext{
Traumatization in Individual and Collective Dimensions: Insights from Biblical Studies and Beyond (ed. Eve-Marie Becker, Jan Dochhorn and Else K. Holt; Goettingen: Vandenhoeck \& Ruprecht, 2014), 25.

126 Denise Dombkowski Hopkins and M.S. Koppel, "Lament Psalms through the Lens of Trauma: Psalms 74, 79, and 137," Sacred Spaces: The E-Journal of the American Association of Pastoral Counselors 9 (2017): 22-23.

127 Rick Marrs, "Out of the Depths: The Psalms and Pastoral Care," Leaven 7/3 (1999): 145 [cited 13 February 2021]. Online: https://digitalcommons.pepperdine.edu/leaven/vol7/iss3/7.

128 Westermann, Praise and Lament in the Psalms, 78.

129 The exception appears to be Ps 88 .
} 
The question was raised as to whether lament is a means to change the attitude of the psalmist or the attitude of God. Perhaps the lamenting psalmist is initially more interested in a transaction ("I will do this if you will do that") than a transformation, whereas YHWH is more interested in transforming the person's outlook to one of genuine faith in the midst of trial. Perhaps, too, God's silence enables him to form a new view of himself as someone who can engage God in a transforming way, changing both of them. Manipulation and selfdeception may be part of his hidden transcript but, essentially, he is committed to the covenant-relationship. In the words of Ps 130, another psalm expressing pain, his words might be: "My soul waits for $Y H W H \ldots$ for with $Y H W H$ there is hesed." Part of his waiting may include persuasive attempts but the ultimate purpose of his soul is to depend on YHWH's hesed, a strategy to which the God who initiated the covenant with him must, and will, respond.

\section{F BIBLIOGRAPHY}

Abelson, Robert P. and David E. Kanouse. "Subjective Acceptance of Verbal Generalizations." Pages 171-197 in Cognitive Consistency. Edited by Shel Feldman. New York: Academic Press, 1966.

Ahearne-Kroll, Stephen P. 2006. "Challenging the Divine: LXX Psalm 21 in the Passion Narrative of the Gospel of Mark." 119-148. https://www.academia.edu/9393723/Challenging the_Divine_LXX_Psalm_22 in the Passion_Narrative of the Gospel_of_Mark.

Al-Houdalieh, Salah H. "Visitation and Making Vows at the Shrine of Shaykh Shihb Al-Di" N." Journal of Islamic Studies 21/1 (2010): 377-390.

Austin, John L. How to Do Things with Words. 2nd edition. Oxford: Clarendon Press, 1975.

Bayer, John. (O. Cist.). "Living toto corde: Monastic Vows and the Knowledge of God." Religions 10/424 (2019): 1-14.

Berkowitz, Leonard and Louise R. Daniels. "Responsibility and Dependency." Journal of Abnormal and Social Psychology 2 (1965): 247-254.

Bosworth, David A. House of Weeping. The Motif of Tears in Akkadian and Hebrew Prayers." ANE Monographs 24. Atlanta: SBL, 2019.

Broyles, Craig C. The Conflict of Faith and Experience in the Psalms. A Form-critical and Theological Study. Sheffield: JSOT Press, 1989.

Brueggemann, Walter. "Lament as Wake-up Call (Class Analysis and Historical Possibility)." Pages 221-236 in Lamentations in Ancient and Contemporary Cultural Contexts. Edited by Nancy C. Lee and Carleen Mandolfo. Atlanta: SBL, 2008.

1984. The Message of the Psalms. Minneapolis: Augsburg, 1984.

1997. Theology of the Old Testament: Testimony, Dispute, Advocacy. Minneapolis: Fortress Press, 1997.

Old Testament Theology: Essays on Structure, Theme and Text. Minneapolis: Fortress Press, 1992.

. The Psalms and the Life of Faith. Minneapolis: Fortress Press, 1995.

Bullock, C. Hassel. Encountering the Book of Psalms. Grand Rapids: Baker Books, 2001. 
Buss, David M., Mary Gomes, Dolly S. Higgins and Karen Lauterbach. "Tactics of Manipulation." Journal of Personality and Social Psychology 52/6 (1987): 1219-1229.

Castelfranchi, Cristiano. "Reasons: Beliefs Structure and Goal Dynamics." Mathware \& Soft Computing 3/2 (1996): 233-247.

Castelfranchi, Cristiano and Marco Guerini. "Is It a Promise or a Threat?" Pragmatics and Cognition (2007). https://www.researchgate.net/publication/233583284.

Chaiken, Shelly L., Deborah H. Gruenfeld and Charles M. Judd. "Persuasion in Negotiations and Conflict Situations." Pages 144-165 in The Handbook of Conflict Resolution: Theory and Practice. Edited by Morton Deutsch and Peter T. Coleman. San Francisco: Jossey-Bass Publishers, 2000.

Cilliers, Johan. "Breaking the Syndrome of Silence: Finding Speech for Preaching in a Context of HIV and AIDS." Scriptura 96 (2007): 391-406.

Cohen, Philip R. and Hector Levesque. "Persistence, Intention, and Commitment." Pages 33-70 in Intentions in Communication. Edited by Philip R. Cohen, Jerry Morgan and Martha E. Pollack. Boston: MIT Press, 1990.

Cohen, Sheldon. Behavior, Health, and Environmental Stress. New York: Plenum Press, 1986.

Deverell, Garry J. "If It Be Your Will: Making Promises with Derrida, Ricoeur and Chauvet." Pacifica: Australasian Theological Studies 16/3 (2003): 271-294.

Dombkowski Hopkins, Denise. 2016. Psalms: Books 2-3. Wisdom Commentary 21. Collegeville: Liturgical Press.

Dombkowski Hopkins, Denise and Michael S. Koppel. 2017. "Lament Psalms through the Lens of Trauma: Psalms 74, 79, and 137." Sacred Spaces: The E-Journal of the American Association of Pastoral Counselors 9: 7-32.

Eade, Caroline. "Promises, Promises." Cambridge Papers towards a Biblical Mind 16/4 (2007). Cited 12 March 2021. Online: https://www.jubileecentre.org/cambridge-papers/promises-promises-by-caroline-eade.

Egan, Louisa C. "Self-deception Is Adaptive in Itself." Behavioural and Brain Sciences 34/1 (2011): 19-20.

Fernyhough, Charles. The Voices Within: The History and Science of How We Talk to Ourselves. New York: Basic, 2016.

Flesher, LeAnn S. "Rapid Change of Mood: Oracles of Salvation, Certainty of a Hearing, or Rhetorical Play?" Pages 33-45 in "My Words Are Lovely": Studies in the Rhetoric of the Psalms. Edited by Robert L. Foster and David M. Howard Jr. New York: T\&T Clark, 2008.

Frechette, Christopher G. "Destroying the Internalized Perpetrator: A Healing Function of the Violent Language against Enemies in the Psalms." Pages 71-84 in Trauma and Traumatization in Individual and Collective Dimensions: Insights from Biblical Studies and Beyond. Edited by Eve-Marie Becker, Jan Dochhorn and Else K. Holt. Goettingen: Vandenhoeck \& Ruprecht, 2014.

Guerini, Marco and Cristiano Castelfranchi. "Promises and Threats in Persuasion." Pages 14-21 in Computational Models of Natural Argument VI, 2006. http://cmna.csc.liv.ac.uk/CMNA6/CMNA06Guerini.pdf.

Gunkel, Hermann. The Psalms. Philadelphia: Fortress Press, 1967.

Gunkel, Hermann and J. Begrich. Introduction to Psalms: The Genres of the Religious Lyric of Israel. Mercer University Press, 1998. 
Hahn, Frances H. "Performing the Sacred: Prayers and Hymns." Pages 235-248 in A Companion to Roman Religion. Edited by Jörg Rupke. Oxford, UK: Blackwell Publishing, 2007.

Herman, Judith L. Trauma and Recovery. The Aftermath of Violence: From Domestic Abuse to Political Terror. New York: Basic Books, 1992.

Hershfield, Hal E., Taya R. Cohen and Leigh Thompson. "Short Horizons and Tempting Situations: Lack of Continuity to Our Future Selves Leads to Unethical Decision Making and Behavior." Advances in Consumer Research 40 (2012): 22-27. https://www.acrwebsite.org/volumes/v40/acr_v40_13180.pdf.

Hess, Carol L. "Becoming Mid-wives to Justice: A Feminist Approach to Practical Theology." Pages 51-74 in Liberating Faith Practices: Feminist Practical Theologies in Context. Edited by Denise Ackermann and Riet Bons-Storm. Leuven: Peeters, 1998.

Hwang, Jerry. “'How Long Will My Glory Be Reproach?' Honour and Shame in Old Testament Lament Traditions." Old Testament Essays 30/3 (2017): 684-706.

James, Peter G. 2012. "Promises to Keep." Sermons from Vienna Presbyterian Church, 29 January 2012.

Katz, Elihu, Michael Gurevitch, Brenda Danet, and Tsiyona Peled. 2008. "Petitions and Prayers: A Method for the Content Analysis of Persuasive Appeals." Chapter 5 (pages 269-344) in K. Krippendorff and M.A. Bock, The Content Analysis Reader, 1st Edition. Newbury Park, CA: Sage.

Kay, Aaron C., Danielle Gaucher, Jaime L. Napier, Mitchell J. Callan and Kristin Laurin. "God and Government: Testing a Compensatory Control Explanation for the Support of External Systems." Journal of Personality and Social Psychology 95 (2008): 18-35.

Keel, Othmar. The Symbolism of the Biblical World: Ancient Near East Iconography and the Book of Psalms. New York: Seabury, 1978.

Kellerman, Ulrich. "Psalm 137." Zeitschrift für die Alttestamentliche Wissenschaft 90/1 (1978): 43-58.

Kennedy, Duncan. "Distributive and Paternalist Motives in Contract and Tort Law, with Special Reference to Compulsory Terms and Unequal Bargaining Power." Maryland Law Review 41/4 (1982): 564-658.

Kim, Sarah and Ann L. McGill. "Helping Others by First Affirming the Self: When Self-affirmation Reduces Ego-defensive Downplaying of Others' Misfortunes." Personality and Social Psychology Bulletin 44/3 (2018): 345-358.

Lavoie, Jean-Jaques. "'Laisse Aller ton Pain sur la surface des eaux' Étude Qohélet 11,2." Pages 75-90 in The Language of Qohelet in Its Context. Edited by Angelika Berlejung and Pierre Van Hecke. Leuven: Peeters, 2007.

Levenson, Jon D. Creation and the Persistence of Evil. Princeton: Princeton University Press, 1994.

Levytska, J.A. 2015. “Argument as a Way of Persuasion.” Yaroslav the Wise National Law University. http://molodyvcheny.in.ua/files/conf/fil/06may2015/06may2015.pdf\#page $=10$ $\underline{6 .}$

Lucaci, Bujorel. 2011. "YHWH's Absence or Hostility as Two Main Motifs of Suffering and Protest in Lament Psalms: A Theo-dramatic Approach." MA thesis. Melbourne College of Divinity. 
Mandolfo, Carleen. God in the Dock. Dialogic Tension in the Psalms of Lament. Sheffield: Sheffield Academic Press, 2002.

Mandolfo, Carleen. "Talking Back: The Perseverance of Justice in Lamentations." Pages 47-56 in Lamentations in Ancient and Contemporary Cultural Contexts. Edited by Nancy C. Lee and Carleen Mandolfo. Atlanta: SBL, 2008.

Mare, Leonard P. "Psalm 137: Exile - Not the Time for Singing the Lord's Song." Old Testament Essays 23/1 (2010): 116-128.

Marrs, Rick. 1999. "Out of the Depths: The Psalms and Pastoral Care." Leaven 7(3): Article 7. https://digitalcommons.pepperdine.edu/leaven/vol7/iss3/7.

Neary, Michael. "The Importance of Lament in the God/Man Relationship in Ancient Israel." The Irish Theological Quarterly 52/3 (1986): 180-192.

O'Connor, Kathleen M. Lamentations and The Tears of the World. Maryknoll: Orbis Books, 2002.

Odell, John. 2009. "Negotiating from Weakness in International Trade Relations." Presented at the University of California, Irvine, 28 May 2009.

Odell, John S. "Negotiation and Bargaining." Handbook of International Relations. 2nd edition. Edited by Walter Carlsnaes, Thomas Risse and Beth A. Simmons. Thousand Oaks: Sage Publications, 2012.

Perelman, Chaïm and L. Olbrechts-Tyteca. TheNnew Rhetoric: A Treatise on Argumentation. Dame: Notre Dame Press, 1969.

Plastaras, James. The God of Exodus. Milwaukee: Bruce Publishing Co., 1966.

Poser, Ruth. "No Words: The Book of Ezekiel as Trauma Literature and a Response to Exile." Pages 27-48 in Bible through the Lens of Trauma. Edited by Elizabeth Boase and Christopher G. Frechette. Semeia Series 86. Atlanta: SBL Press, 2016.

Poulakos, John. "Review of Scott R. Stroud, Kant and the Promise of Rhetoric." KSO (2016): 44-45.

Provan, Iain. Lamentations. The New Century Bible Commentary. Grand Rapids: Eerdmans, 1991.

Saliers, D.E. "Psalms in Our Lamentable World." Yale Journal of Music \& Religion 1/1 (2015): Article 7.

Schmitt, David R. “The Invocation of Moral Obligation.” Sociometry 27 (1964): 299310.

Schopler, John and Nicholas Bateson. "The Power of Dependence." Journal of Personality and Social Psychology 2 (1965): 247-254.

Scott, James C. Domination and the Arts of Resistance: Hidden Transcripts. Yale University Press, 1990.

Searle, John. Speech Acts. Cambridge, UK: Cambridge University Press, 1969.

Steele, Claude M. "The Psychology of Self-affirmation: Sustaining the Integrity of the Self." Advances in Experimental Social Psychology 21 (1988): 261-302.

Steinel, Wolfgang and Carsten K.W. De Dreu. "Social Motives and Strategic Misrepresentation in Social Decision Making." Journal of Personality \& Social Psychology 86 (2004): 419-434.

Steiner, Richard C. "Does the Biblical Hebrew Conjunction - ו Have Many Meanings, One Meaning, or No Meaning at All?" Journal of Biblical Literature 119/2 (2000): 249-267.

Stoebe, H.J. חסד, TLOT v. 2. Peabody: Hendrickson, 1997. 
Van Dijk, Teun A. “Discourse and Manipulation.” Discourse and Society 17/3 (2006): 359-383.

Villanueva, Federico G. The 'Uncertainty of a Hearing': A Study of the Sudden Change of Mood in the Psalms of Lament. Leiden: Brill, 2008.

Von Hippel, William and Robert Trivers. "The Evolution and Psychology of Selfdeception." Behavioural and Brain Sciences 34 (2011): 1-56.

Weber, Beat. "Zum sogenannten 'Stimmungschwung' in Psalm 13.” Pages 116-138 in The Book of Psalms: Composition and Reception. Edited by Peter W. Flint and Patrick D. Miller. VTSup 99. Leiden: Brill, 2005.

Weiser, Artur. The Psalms. Translated by H. Hartwell. OTL. London: SCM, 1962.

Westermann, Claus. Praise and Lament in the Psalms. Louisville: John Knox Press, 1981.

White, James B. Living Speech: Resisting the Empire of Force. Princeton: Princeton University Press, 2006.

Whitson, Jennifer A. and Adam D. Galinsky. "Lacking Control Increases Illusory Pattern Perception." Science 322 (2008): 115.

Williamson, Robert. Jnr. "Lament and the Arts of Resistance: Public and Hidden Transcripts in Lamentations 5." Pages 67-80 in Lamentations in Ancient and Contemporary Cultural Contexts. Edited by Nancy C. Lee and Carleen Mandolfo. Atlanta: SBL, 2008.

Wolterstorff, Nicholas. "Justice as a Condition of Authentic Liturgy." Theology Today 48/1 (1991): 6-21.

Zartman, I. William and Jeffrey Z. Rubin. Power and Negotiation. Ann Arbor: University of Michigan Press, 2000.

Zenger, Erich. A God of Vengeance? Understanding the Psalms of Divine Wrath. Translated by L.M. Maloney. Louisville: Westminster John Knox, 1996.

June F. Dickie, University of Kwa-Zulu Natal, E-mail: junedickie@ gmail.com,

ORCID: https://orcid.org/0000-0002-5226-5874 